Valentyna Hladkova ORCID iD 0000-0003-4362-2195

Doctor of Sciences (Pedagogy), Professor, Professor of the Department of Management,

Boris Grinchenko Kyiv University, 13-b Tymoshenko Str., 04212 Kyiv, Ukraine, v.hladkova@kubg.edu.ua

\title{
ADAPTIVE CONTROL OF PERSONNEL RESERVE TRAINING IN INSTITUTION OF HIGHER EDUCATION
}

The article reveals the essence and peculiarities of the personnel reserve formation in the institution of higher education. The functionality of the personnel reserve of the modern higher school is analyzed from two viewpoints: the viewpoint of an institution of higher education (functions are information, personnel planning, resource saving, anti-crisis, regulatory) and the viewopoint of a reservist (career-orientation, motivational, developmental functions). The personnel reserve management is represented by several approaches: classical (training is tied to the competence of a particular position); the personnel reserve management in the context of the concept of talent management (development on the grounds of needs and deficits in the competence of succession pool members); synthetic (the personnel reserve is a self-organized community and a training program). The best thing is to use adaptive control technology in order to regulate relationships between members of the personnel reserve, and assist them in the implementation of professional self-development and self-improvement. Adaptive control is founded on the acme-synergic principles, as it provides favorable conditions for selforganization, self-knowledge, self-understanding, self-determination, self-prediction and self-design, self-actualization and self-realization of a person as a subject of professional activity. Main lines of work of the acme-synergic service are informational-analytical (general department); organizational-designing (prognostic department); acmeologicaltechnological (technological department); psychological (department of acme-synergic support); research (analytical department).

Key words: acmeology; acme-synergic supply service; adaptive control; functions of personnel reserve; personnel reserve.

https://doi.org/10.28925/1609-8595.2019.2.3540

Introduction. A modern higher school needs an active staffing strategy. It is necessary to create the optimal conditions for the personnel reserve formation and its effective use for the purpose of the human resources management. Currently, a clear-cut personnel policy based on the professional growth and improvement of the scientific-pedagogical and administrative staff is the priority direction for a board of institutions of higher education.

As of today, the so-called personnel «emptiness» has occurred in the staffing structure of the higher school, meaning a lack of not merely employees of early adulthood (25-35 years) but also ones of middle age (35-50 years). At the same time, a significant turnover of personnel is observed which is caused not only by insufficient material provision, but also by rough conditions for professional development, career advancement, etc. A personnel reserve formation of scientific-pedagogical and administrative personnel, its establishment and maintenance will facilitate correction of such inconsistencies.

Initial preconditions. The issue of the personnel reserve formation in educational institution is explored by contemporary scholars. By so doing, O. L. Nosov (2015a, 2015 b) considers approaches to the staffing reserve formation of an institution of higher education, analyzes the concept of logistic approach to personnel flows. According to the scientist, evaluation, formation and management of competencies deserve special emphasis within the personnel reserve formation. Yu. Habtrakhmanova (2010) represents a generalized mechanism for the formation and management of a personnel reserve in the field of education taking into account the classification by the groups of employees. Researchers combine personnel reserves efforts with career planning and adjustable rotation (Durakova, 2009). However, the published results of the research do not speak that best practice of a personnel reserve demands to take into consideration the social and temporal peculiarities of its functioning in educational institutions, modern trends of the educational process management.

The research objective is to identify the peculiarities of adaptive control of the personnel reserve training in institutions of higher education. It is necessary to analyze the selection technology into the personnel reserve of the institution of higher education and develop measures of adaptive control of personnel reserve training on an acmesynergic basis to achieve the above mentioned object.

The features of the personnel reserve formation at the university. The concept of «personnel reserve» is not something new. As far back as times of Soviet there was a form of annual reporting on the state of work with the personnel reserve at the enterprises. However, nowadays systematic operation with succession pool members (notably in institutions of higher education) is not 
carried out in large or occurs at the stage of formation, since «reservists» do not always have the possibility to occupy the position they intend for a while being in reserve (Kadrovyy rezerv TPU).

Personnel reserve is a group of managers and specialists possessing the ability to manage, systematic targeted training, meeting the requirements imposed by the position of a particular rank, and have made it past filter (Maslov, 2015).

The features of the personnel reserve formation at the university are analyzed by D. Dzevanivska (2015). The scientist notes that the personnel reserve management is represented by several approaches at the Tomsk State University:

- classical (training is tied to the competence of a particular position; entry into the personnel reserve is conducted according to the recommendation of the board; evaluation is multilevel);

- management in the context of the concept of talent management (entry into the personnel reserve through self-nomination; development on the grounds of needs and deficits in the competence of succession pool members; the development program mobilizes reservists around urgent tasks of the organization),

- synthetic (development is built on the basis of needs and deficits in the competence of succession pool members with a focus on career advancement; the management results are professional growth, development of professional competencies of the highest standards, projects for the crucial tasks of the organization; the personnel reserve is a self-organized community and a training program).

The personnel reserve is divided into 2 groups: a reserve of scientific-and-pedagogical workers and administrative and managerial personnel.

As modern researchers point out, «... generation process a personnel reserve of a university means the creation of such a reserve possessing sufficient level of mobility, intellectual activity, physical and mental health, and capacity to adapt rapidly to new working conditions» (Godymchuk et al., 2008).

Personnel reserve formation of an organization is determined by the following conditions: intensive organizational development; the manifestation of stagnation associated with the need to change the senior personnel; the transfer of qualified managers to other organizational environment; developed system of staff turnover (horizontal and vertical) (Lazarenko et al., 2016; Murtazin, 2004).

Thegeneration process of astaffreserve usually involves several steps: analysis of personnel reserve requirements; selection of candidates for personnel reserve; formation of the personnel reserve list (operational and strategic).

The functionality of the personnel reserve of the modern higher school is analyzed from two viewpoints: the viewpoint of an institution of higher education (functions are information, personnel planning, resource saving, anti-crisis, regulatory) and the viewpoint of a reservist (career-orientation, motivational, developmental functions) (Kalinin et al, 2015).
The information function of the personnel reserve is manifested in the fact that the organization gets the opportunity to synthesize information on prospective employees, to make a list of their competencies in the process of work with the personnel reserve. Serviceprofessional advancement takes into account the concrete achievements of the worker (defense of the dissertation, publication in professional and scientometric editions, internship, etc.) in modern institutions of higher education also accounted in personnel planning. Permanent and purposeful work with personnel reserve makes it possible to reduce the cost of staff selection and adaptation in the workplace. The essence of the anti-crisis function of the personnel reserve is that its members can assist in situations of sudden staff dismissal of the regular labor force (it especially applies to scientific and pedagogical workers). The regulatory function is crucial for the personnel reserve due to the fact that today the aging of the scientific and pedagogical staff is the development deterrent of modern universities.

If we consider the functions of the personnel reserve from the position of the employee, then it is necessary to focus attention, first of all, on the career-orientation function. A member of the personnel reserve has specific, well-defined benchmarks for personal and professional growth, the opportunity to assess his chances of getting the desired position. The personnel reserve status motivates the employee to personal and professional growth (external from the point of the higher school side and internal motivation). The developmental function of the personnel reserve consists in the fact that training in different directions is the obligatory element of work with the personnel reserve (given to the personality of each reservist).

The best thing is to use adaptive control technology in order to regulate relationships between members of the personnel reserve, and assist them in the implementation of professional self-development and self-improvement.

Many contemporary scientists tackled the issues of adaptive control: T. Borova, T. Davidenko, H. Yelnikova etc. As H. Yelnikova (2011) notes, «Adaptive control is a process of mutual influence causing the mutual adaptation of the behavior of actors on the dia(poly) logical basis, which is ensured by a joint definition of a realistic objective with a subsequent combination of efforts and self-directed actions in order to achieve it. The major feature of adaptive control is the mutual adaptation and the organic combination of the manager's goal and the pursuit of the executor based on the development of flexible activity models».

Adaptive control is founded on the acme-synergic principles, as it provides favorable conditions for selforganization, self-knowledge, self-understanding, selfdetermination, self-prediction and self-design, selfactualization and self-realization of a person as a subject of professional activity.

The personnel reserve status of a higher school promotes the development of professional competence, which is a complex formation including certain special types of competence, among which the leading role 
plays acmeological competence as the most important condition for the professionalism of administrative/ scientific-pedagogical staff. The high level of acmeological competence enables specialists to carry out effective professional performance, professional self-improvement and self-realization.

The formation and further development of autopsychological competence is significant for each reservist that is the readiness and ability of the actors to work purposefully and psychologically on the change of personality traits and behavioral characteristics. The algorithm for the formation of auto-psychological competence involves the consistent implementation of the following stages: actualization of personal and professional problems; formation of the self-transformative activity subject; the task of the indicative basis of selftransformative actions; formation of operational and technological component of self-transformative activity; the transition from external (materialized) to internal (psychological) actions.

Auto-psychological competence is a part of the acmeological competence representing the integral ability of a person to build his progressive development in various spheres of activity under the conditions of continuous complication of tasks and growth of achievement levels that require the maximum realization of human psychological resources. The high level of acmeological competence enables employees of higher educational establishments to conduct effective professional activity, professional self-improvement and self-realization.

In order to develop a program for the reservist development, it is necessary to create a bank of professional competencies used in hiring new employees and in the further professional support of active workers on the way of professionalization and implementation of career advancement.

The next step covers identifying shortage and overage in the content of each competence according to the norm. Such a detailed elaboration list underlies the reason for the development of the acmeological trajectory of self-improvement and self-realization in the direction towards professionalization and career advancement for each member of the personnel reserve of an institution of higher education, as well as an acme-synergic support on this path.

It should be separately emphasized acmeological competence constituting a high level of possession strategies and technologies of personal and professional self-development and self-improvement with subsequent self-realization in life among educational institution employees. The primary components of acmeological competenceare reflexive, prognostic, projective, cognitive, operational, organizational, communicative, and others. Reflexive component contains self-evaluation strategies, self-assessment and effective self-control in professional activities. The projective component is characterized by strategies for predicting, planning and implementing self-transformative activities. The cognitive component includes a strategy for SWOT analysis. The operational component involves an analysis of the subject's ability to personal and professional development. Organizational component is revealed through self-mobilization, selfmanagement, disclosure and development of the potential for effective self-realization in professional activity. The components of the communicative component are perceptual perceiving, constructive interaction and the creation of a success zone in social contacts (Hladkova, 2013, p. 222-223).

The emphasis is made on auto-psychological and acmeological competencies within the process of development and further implementation of the acmesynergic technologies of personal and professional selfimprovement. In our opinion, acme-futuring is an effective tool for the development of such technologies, notably prediction and active foresight of self-development, self-improvement and further self-realization towards ACME. We suggest varieties of acme-futuring: «Ability acme-futuring is acme-futuring, the main object of which is the properties (personal and professional), and the goal is the formed akmeologic invariants... Synergic acmefuturing is acme-futuring subjecting to the personality as an open system constantly developing and effectively self-realizing despite the barriers and «katabole» to reach the excellence» (Hladkova, 2013, p. 224-225).

The process of professional development (selfdevelopment) and improvement (self-improvement) of the reservist involves moving from the professional reality-ego to the professional superego that is to the level of excellence. This process is subjected to the influence of the extra-environment (external) and intra-environment (internal), where the relevant factors apply. The macroenvironment (extra-environment) influences on the development (self-development) and improvement (self-improvement) through the external factors (conditions and attributes), and the intra-environment contains internal factors (personal, subjective qualities) contributing or interfering with the process. The process itself takes place in the meso-environment (interenvironment), where integrative meso-factors operate as acmeological invariants, catabolic factors, as well as factors accelerating or slowing down this process. The above-mentioned environment is acme-synergic.

Achievement of the heights of personal and professional development is impossible without the use of fundamental acmeology knowledge by a specialist. We propose the following procedure for mastering the method of acmeological design in the process of professional becoming and further development of a specialist:

1. Insight into the particular nature of the professional activity of a specialist. The result of such actions can be both pragmatic and psychological. A pragmatic result is professional-qualification characteristic of the employee in a certain sphere; psychological one is knowledge of the essence of the psychological characteristics of the worker and his professional activities.

2. Critical analysis of professional activity of a specialist. A pragmatic result is the characteristic «Professional activity of a specialist (PAF)». A psychological result is the ability to perform professional actions. 
3. Analysis in the framework of the professional activity for each action and result. A pragmatic result is the «Action-Result» scheme for a specialist. A psychological result is the ability to analyze activity, highlighting purpose, motives, actions, result.

4. Systematization of all the previous material for the construction of the acmeogram for a specialist. A pragmatic result is an acmeogram of a specialist. A psychological result is the ability to perform analysis, synthesis, comparison, abstraction, systematization of the material.

5. Creation of the author's system of personal and professional development and self-development. A pragmatic result is the trajectory of personal and professional development aimed at the fullest possible self-realization. A psychological result is the ability to predict the future relying on reality.

The specialist acquires the necessary acmeological knowledge, forms skills, gains experience in the process of acme-synergic design of the author's program of personal and professional self-development. We emphasize precisely on acmeological knowledge, because it is in its essence:

- integrative (on the one hand, it relies on the idea of a person as an individual, personality, subject of activity, individual, and on the other - on the theory of pedagogical systems, psychology and acmeology of management);

- personally oriented (it is aimed at the individual style formation of professional activity subjected to the common patterns, at the development of internal potential towards personal and professional heights);

- technological (equipping every manager with algorithms and techniques of detection, development design and implementation of their own creative potential, individuality on the way to personal and professional heights as skill, uniqueness.

The proposed system of acme-synergic design facilitates to build the ability of a specialist not merely to perform effectively the functions of professional engagement, but also actively, consciously develop and polish his personality to achieve the acmes of professionalism in certain activities.

Auto-professional competence could be evaluated according to the following indicators: behavioral and intellectual flexibility; adaptability; capacity to selfmanagement (of own development, emotional states); high level of motivation not limited to the result, but also to the process of self-improvement and selfrealization; adequacy of self-esteem; self-identification in the profession, etc. Acme-synergic support is the final stage in the formation of auto-professional competence, which can be carried out in the form of individual and group counseling, periodic psycho-diagnostics, corrective work (training, quasi-professional traditional games), developmental training, quasi-professional innovative games, preventive conversations, coaching, etc. The choice of a concrete form of acme-synergic support depends on each particular subject aspiring to maximize self-realization on the path to mastery, his ACME.
Creation of the acme-synergic support service for professional development is appropriate for the effective development (self-development) and improvement (selfimprovement) of reservists.

The main objective of the acme-synergic support service for professional development is the acme-synergic maintenance of the systemic support of personnel potential development in institutions of higher education.

Several goals are psychological and acmeological support of personnel work; psycho-acmeological optimization of work, professional interactions and relations of administrative and scientific-pedagogical workers in higher educational establishments; acmesynergic support for the personal and professional development of reservists; acmeological assistance in forming an effective image and authority of the administrative and scientific-pedagogical staff of the university.

Main lines of work of the acme-synergic service are informational-analytical (general department); organizational-designing (prognostic department); acmeological-technological (technological department); psychological (department of acme-synergic support); research (analytical department).

Successfully functioning acme-synergic service is intended to assist personal and professional development, within the framework of which such progressive changes occurs in personality as:

- personality orientation changes (expanding the range of interests and changing the system of needs, actualizing the motives of achievement, increasing the need for self-improvement and self-realization, enlarging creativity of the individual);

- enhanced experience as well as qualifications (intensifying competence, developing and expanding skills, mastering new algorithms for solving professional problems, increasing creativity of activities);

- development of complex individual abilities;

- elaboration of professionally important qualities in accordance with the specifics of the activity;

- development of personal and business qualities;

- increased acmeological readiness for actions in various situations including extreme;

- development of acmeological invariants of professionalism, the key qualities and skills of a professional providing a high stable performance of the activity regardless of its content and specificity.

Conclusions and directions for future research. The personnel reserve training for the scientific, pedagogical and administrative staff of the institution of higher education requires adaptive control based on the acmesynergic principles. The acme-synergic support service is suggested for the professional support of the reservists and designed to assist and encourage the personnel reserve members underway towards maximization of their selfrealization and career advancement. Directions for future research are observed in the development of acmeological technology for the personnel reserve training in an institution of higher education. 


\section{References}

Gabtrakhmanova, Yu. T. (2010). Mekhanizm upravleniya kadrovym rezervom v vysshem uchebnom zavedenii [The mechanism of personnel reserve management in higher education]. Vestrik IrGTU, 4 (44), 194-197 (rus).

Hladkova, V. M. (2013). Profesiine samovdoskonalennia menedzheriv vyshchykh navchalnykh zakladiv: akmeolohichni osnovy: Monohrafiia [Professional self-improvement of managers of higher educational institutions: acmeological foundations: Monograph]. Kyiv, Ukraine: Osvita Ukrainy (ukr).

Godymchuk, A. Yu., Kozlova, N. V., Volkov, Yu. V., Dolmatov, O. Yu. (2008). Formirovanie kadrovogo rezerva v vuze [Formation of personnel reserve in the university]. Universitetskoe upravlenie: praktika i analiz, 6, 52-56 (rus).

Dzevanovskaya, D. D. (2015). Osobennosti formirovaniya kadrovogo rezerva v universitete [Formation of personnel reserve in the university]. Molodoy uchenyy, 10, 627-630 (rus).

Yelnykova, H. V. (2011). Tekhnolohiia adaptyvnoho upravlinnia personalom. [Technology of adaptive personnel management]. Naukovij visnik Institutu profesijno-tehnichnoyi osviti NAPN Ukrayini. Seriya: Profesijna pedagogika, $1,8-146(\mathrm{ukr})$.

Kadrovyy rezerv TPU [Staff reserve TPU]. Upravlenie po rabote s personalom. Tomskij politehnicheskij universitet. Retrieved from http://www.tpu.ru/html/reserve.htm (rus).

Kalinin, P. A., Varankina, S. V., Nemchaninova, Ye. N. (2015). Kadrovyy rezerv sovremennogo vuza kak funktsiya menedzhmenta obrazovatelnoy organizatsii. [Personnel reserve of a modern university as a function of management of an educational organization]. «Innovatsii v nauke»: sbornik statey po materialam XLVIII mezhdunarodnoy nauchno-prakticheskoy konferentsii. (31 avgusta 2015 g.). Retrieved from https://sibac.info/conf/innovation/ xlviii/42782 (rus).

Lazarenko, V. A., Nikishina, V. B., Petrash, Ye. A., Sorokina, N. N. (2016). Kompetentnostnaya model otsenki kadrovogo rezerva vuza [Competency model for assessing the personnel reserve of the university]. Voprosy upravleniya, 2 (rus).

Murtazin, R. R. (2004). Upravlencheskiy rezerv kompanii [Company management reserve]. Spravochnik po upravleniyu personalom, 10, 97 (rus).

Nosov, A. L. (2015). Formirovanie effektivnogo mekhanizma upravleniya kompetentsiyami. [Formation of an effective competence management mechanism]. Kontsept, 5 (rus).

Nosov, A. L. (2015). Opyt formirovaniya kadrovogo rezerva v uchebnom zavedenii [Experience in the formation of personnel reserve in the school]. Traektoriya nauki, 5 (rus).

Durakova, I. B. (Ed.). (2009). Planirovanie i podgotovka rezerva rukovoditeley [Planning and training reserve managers]. In Upravlenie personalom. Moskow, Russia: INFRA-M (rus).

Rabota s kadrovym rezervom. Planirovanie karery. Reguliruemaya rotatsiya [Work with personnel reserve. Career planning. Adjustable rotation]. URL: http://hrm.ru/db/hrm/0846367C62CC156A44257B120049111E/show/ conference/support_card.html (rus).

Maslova, V. M. (Ed.). (2015). Formuvannia kadrovoho rezervu i robota z nym [Formation of personnel reserve and work with it]. In Upravlenie personalom (pp. 256-269). Moskow, Russia: Yurajt (rus).

\section{Література}

Габтрахманова Ю. Т. Механизм управления кадровым резервом в высшем учебном заведении. Вестник ИрГТУ. 2010. № 4 (44). C. 194-197.

Гладкова В. М. Професійне самовдосконалення менеджерів вищих навчальних закладів: акмеологічні основи: Монографія. Київ: Освіта України, 2013. 350 с.

Годымчук А. Ю., Козлова Н. В., Волков Ю. В., Долматов О. Ю. Формирование кадрового резерва в вузе. Университетское управление: практика и анализ. 2008. № 6. С. 52-56.

Дзевановская Д. Д. Особенности формирования кадрового резерва в университете. Молодой ученъии. 2015. № 10. С. $627-630$.

Єльникова Г. В. Технологія адаптивного управління персоналом. Науковий вісник Інституту професійнотехнічної освіти НАПН України. Серія: Професійна педагогіка. 2011. № 1. С. 8-14.

Кадровый резерв ТПУ. Управление по работе с персоналом. Томский политехнический университет. URL: http:// www.tpu.ru/html/reserve.htm (дата звернення 10.05.2019).

Калинин П. А., Варанкина С. В., Немчанинова Е. Н. Кадровый резерв современного вуза как функция менеджмента образовательной организации. Инноващии в науке: сборник статей по материалам XLVIII международной научно-практической конференции. (31 августа 2015 г.). URL: https://sibac.info/conf/ innovation/xlviii/42782 (дата звернення 10.05.2019).

Лазаренко В. А., Никишина В. Б., Петраш Е. А., Сорокина Н. Н. Компетентностная модель оценки кадрового резерва вуза. Вопросы управления. 2016. № 2.

Муртазин Р. Р. Управленческий резерв компании. Справочник по управлению персоналом. 2004. № 10. С. 97.

Носов А. Л. Формирование эффективного механизма управления компетенциями. Концепт. 2015. № 5.

Носов А. Л. Опыт формирования кадрового резерва в учебном заведении. Траектория науки. 2015. № 5.

Планирование и подготовка резерва руководителей. Управление персоналом / И. Б. Дуракова (ред.). Москва: ИНФРА-М, 2009. $546 \mathrm{c}$. 
Работа с кадровым резервом. Планирование карьеры. Регулируемая ротация. URL: http://hrm.ru/db/hrm/0846 367C62CC156A44257B120049111E/show/conference/support_card.html (дата звернення 10.05.2019).

Формирование кадрового резерва и работа с ним. Управление персоналом / В. М. Маслова (ред.). Москва: Юрайт, 2015. С. 256-269.

\section{АДАПТИВНЕ УПРАВЛІННЯ ПІДГОТОВКОЮ КАДРОВОГО РЕЗЕРВУ В ЗАКЛАДІ ВИЩОЇ ОСВІТИ}

Гладкова Валентина, доктор педагогічних наук, професор,

професор кафедри управління, Київський університет імені Бориса Грінченка, вул. Тимошенка, 13-б, 04212 Київ, Україна,

v.hladkova@kubg.edu.ua

У статті розкрита сутність та особливості формування кадрового резерву закладу вищої освіти. Функиіі кадрового резерву проаналізовано з двох точок зору: закладу вищої освіти (інформаційна функиія, кадрове планування, ресурсозбереження, антикризова, регуляторна) $і$ точка зору резервіста (кар'єрна, мотиваційна, розвивальна функиії). Управління кадровим резервом представлено кількома підходами: класичним (навчання пов'язане з компетениією конкретної посади; вступ до кадрового резерву проводиться за рекомендацією колегіi; оцінка є багаторівневою); управління кадровим резервом в контексті концепції управління талантами (розвиток вибудовується на основі потреб і дефіщитів в компетенціях резервістів); синтетичний (кадровий резерв $\epsilon$ співтовариством, що самоорганізується, і програмою підготовки кадрів.). Адаптивна технологія управління $\epsilon$ найбільш ефективною для регулювання відносин між иленами кадрового резерву, а також для допомоги їм у здійсненні професійного саморозвитку та самовдосконалення. Адаптивне управління грунтується на принципах акмесинергї, оскільки забезпечує сприятливі умови для самоорганізації, самопізнання, саморозуміння, самовизначення, самопрогнозування і саморозвитку, самоактуалізації та самореалізації особи як суб'єкта професійної діяльності. Запропоновано форми роботи з резервістами і структуру служби акмесинергетичного забезпечення, основні напрями роботи якої передбачають: інформачійно-аналітичну роботу (загальний відділ); організаційно-проектувальну (прогностичний відділ); акмеолого-технологічну (технологічний відділ); психологічну (відділ акмесинергетичної підтримки); дослідження (аналітичний відділ). Перспективи подальших досліджень вбачаємо в розвитку акмеологічної технологї для кадрового резерву в закладах вищої освіти.

Ключові слова: адаптивне управління; акмеологія; кадровий резерв; служба акмесинергетичного забезпечення; функиії кадрового резерву.

\section{АДАПТИВНОЕ УПРАВЛЕНИЕ ПОДГОТОВКОЙ КАДРОВОГО РЕЗЕРВА В ВЫСШЕМ УЧЕБНОМ ЗАВЕДЕНИИ}

Гладкова Валентина, доктор педагогических наук, профессор, профессор кафедры управления, Киевский университет имени Бориса Гринченко, ул. Тимошенко, 13-б, 04212 Киев, Украина, v.hladkova@kubg.edu.ua

В статье раскрыты сущность и особенности формирования кадрового резерва высшего учебного заведения. Функиии кадрового резерва проанализированы с двух точек зрения: высшего учебного заведения (информативная функиия, кадровое планирование, ресурсосбережение, антикризисная, регуляторная) и точки зрения резервиста (карьерная, мотивачионная, развивающая функиии). Управление кадровым резервом представлено несколькими подходами: классическим (обучение связано с компетениией конкретной должности); управления кадровым резервом в контексте концепции управления талантами (развитие выстраивается на основе потребностей и дефицитов в компетенциях резервистов); синтетическим (кадровый резерв является самоорганизующимся сообществом и программой подготовки кадров.). Адаптивная технология управления является наиболее эффективной для регулирования отношений между членами кадрового резерва, а также для помощи им в осуществлении профессионального саморазвития и самосовершенствования. Адаптивное управление основывается на принципах акмесинергии, поскольку обеспечивает благоприятные условия для самоорганизаиии, самопознания, самопонимания, самоопределения, самопрогнозирования, саморазвития, самоактуализации и самореализации личности как субъекта профессиональной деятельности. Предложены формы работы с резервистами и структура службы акмесинергетичного обеспечения, основные направления работы которой предусматривают: информационно-аналитическую работу (общий отдел); организационно-проектировочную (прогностический отдел); акмеолого-технологическую (технологический отдел); психологическую (отдел акмесинергетической поддержки); исследования (аналитический отдел).

Ключевые слова: акмеология; адаптивное управление; кадровый резерв; служба акмесинергетического обеспечения; функиии кадрового резерва. 